\title{
Seasonal Depth-Related Gradients in Virioplankton: Lytic Activity and Comparison with Protistan Grazing Potential in Lake Pavin (France)
}

\author{
Jonathan Colombet • Télesphore Sime-Ngando
}

Received: 8 November 2011 / Accepted: 17 February 2012 / Published online: 6 March 2012

(C) Springer Science+Business Media, LLC 2012

\begin{abstract}
This study presents an original depth-related survey of virioplankton lytic activity in relation to prokaryotic production and potential protistan bacterivory in the deep $\left(Z_{\max }=92 \mathrm{~m}\right)$ meromictic volcanic Lake Pavin (Massif Central, France). The sampling strategy was designed to be representative of the physico-chemical gradients of the water column of the lake, and of the seasonal variability as well, i.e. 12 different depths sampled in triplicates from April to December 2005. In the space, viral lytic activity estimated from the frequency of visibly infected prokaryotic cells and from burst size over the study period generally decreased with depth. This was viewed as a paradox compared to the abundances of viruses and prokaryotes and to the prokaryotic production which increased with depth. The seasonal variability in viral lytic activity was correlated with prokaryotic variables (abundance and production) in the deepest waters, i.e. from the hypolimnion downwards. Compared to previous studies known from the mixolimnion, we conclude that the deep waters in Lake Pavin represent an exclusive environment for heterotrophic prokaryotes whose seasonal activity offers an optimal and unique resource for thriving viral communities, some of which may be typical, endemic to the ambient dark, cold and stable deep water masses. Overall, the main findings in the present study get well around a previous statement that the ecology of the deepest waters of Lake Pavin is essentially driven by the dark viral loop (dissolved organic matter-prokaryotesviruses) processes, which can sequester organic matters and nutrients for a long-lived turnover time. This is in
\end{abstract}

J. Colombet $\cdot$ T. Sime-Ngando $(\bowtie)$

Laboratoire Microorganismes: Génome et Environnement,

Clermont Université Blaise Pascal, UMR CNRS 6023,

24 avenue des Landais, BP 80026, 63171 Aubière, France

e-mail: telesphore.sime-ngando@univ-bpclermont.fr agreement with recent demonstrations from marine systems that meso- and bathypelagic waters are optimal environments for viral survival and proliferation.

\section{Introduction}

It is now widely accepted that prokaryotes (hereafter referred to as bacteria) play a major role in the cycling of energy and matter in aquatic ecosystems. The related concepts of 'microbial loop' in which nutrients are recycled through bacteria-grazer interactions [3], and of 'microbial food web' that includes the relationships between heterotrophic and autotrophic microorganisms and their connections to biogeochemical cycles $[19,51]$, have stimulated a large amount of researches on the mechanisms which regulate bacterioplankton biomass and activities. Some authors have argued that bacteria are mainly controlled by resources $[7,9$, 19], and others that bacterial mortality is largely due to protistan grazing [24, 53]. Ducklow and Carlson [23] have shown, based on theoretical considerations, that the control mechanisms of bacterioplankton may change seasonally, which matches well with the general empiric finding that the effects of grazers and viruses change with time and space (cf. [47]).

In the late 1980s, it was shown that viral particles occur in great numbers, often exceeding bacterial numbers in marine and freshwaters $[4,50,60]$. Most of these viruses are considered as bacterial viruses (bacteriophages) and their lytic activity as an additional mechanism that significantly contributes to the regulation of bacterial production. It was estimated that bacterial production lysed by viruses in both marine and freshwaters averages $10-40 \%[58,70]$. The loss of bacterial biomass caused by grazing or by virusmediated lysis has different consequences for organic matter 
fluxes. If a major part of bacterial loss is due to viruses, carbon is burned into a dissolved organic carbon (DOC)bacteria-DOC loop [13], while protozoan grazing transfers part of bacterial carbon up to the higher trophic levels [17, 22]. It is thus important to study the contributions of viruses and protists in the control of aquatic prokaryotes.

Numerous studies have investigated, simultaneously and at the community level, the effects of protistan bacterivory and of viral bacteriolysis in aquatic systems $[2,6,11,12,18$, 20, 26, 27, 29, 30, 33, 42, 47-49, 55, 65, 67, 71]. However almost all these studies were done at a short time scale, with only those from Bettarel and co-authors [6] and from Pradeep Ram and co-authors [47-49] which have integrated month to month seasonal variability in lakes. These authors have considered only few points in the surface or shallow stratified water column. In viral and microbial ecology, data on seasonal depth-related gradients are lacking, primarily in freshwater lakes. The available information on the depthrelated variability in viral lytic activity in both fresh [20] and marine systems [68] are known from sporadic sampling. These authors reported highly significant changes with depth, particularly irregardless of oxygen concentrations. Vertical gradients in physico-chemical variables are essential in the vertical partitioning of biological variables [45], and the related carbon flows are dependent on the processes that happen through the whole water column [61-63].

In this study, we examine the seasonal variations of viralmediated bacterial mortality related to fine vertical changes in physico-chemical and biological variables in the deep meromictic Lake Pavin. Potential grazing activity from bacterivorous protists was also estimated. The deep, meromictic and dimictic Lake Pavin exhibits a typical vertical succession of physico-chemical conditions [1], offering a unique model to study virus-protozoa-bacteria interactions in relation to physico-chemical and biological depth-related gradients. This study complements a companion paper in which the standing stocks of viruses and microbial communities are examined [21].

\section{Materials and Methods}

Study Site and Sample Collection

Lake Pavin (altitude, 1,197 m) is a meromictic and dimictic oligomesotrophic lake located in the French Massif Central $\left(2^{\circ} 53^{\prime} 12^{\prime \prime} \mathrm{E}, 45^{\circ} 29^{\prime} 41^{\prime \prime} \mathrm{N}\right)$ that experiences partial overturns. It is a typical crater mountain lake characterized by a maximum depth of $92 \mathrm{~m}$ and low surface ( $44 \mathrm{ha}$ ) and catchment (50 ha) areas. A characteristic feature of the physical structure of the lake is the existence of a distinct and permanent chemocline between about $60-$ and $70-\mathrm{m}$ depths that separates the seasonally mixed layer (i.e. mixolimnion) from the monimolimnion. The latter layer is characterized by an elevated and stable conductivity and salinity, and is permanently completely anoxic [1]. Above the chemocline, there is an oxic/anoxic interface between 50- and 60-m depths (Fig. 1). Samples were collected monthly (between 09:00 and 10:00 AM), from April to December 2005 at a central location in the lake by using an 8-L Van Dorn bottle. Sampling was realized at 12 different depths determined from a preliminary study [20] as representative of the physico-chemical gradients of the whole water
Figure 1 Sampling strategy in the water column of Lake Pavin. Example of oxygen and temperature profiles in July, typical of the period of thermal stratification. Characteristic layers and sampled depths are indicated

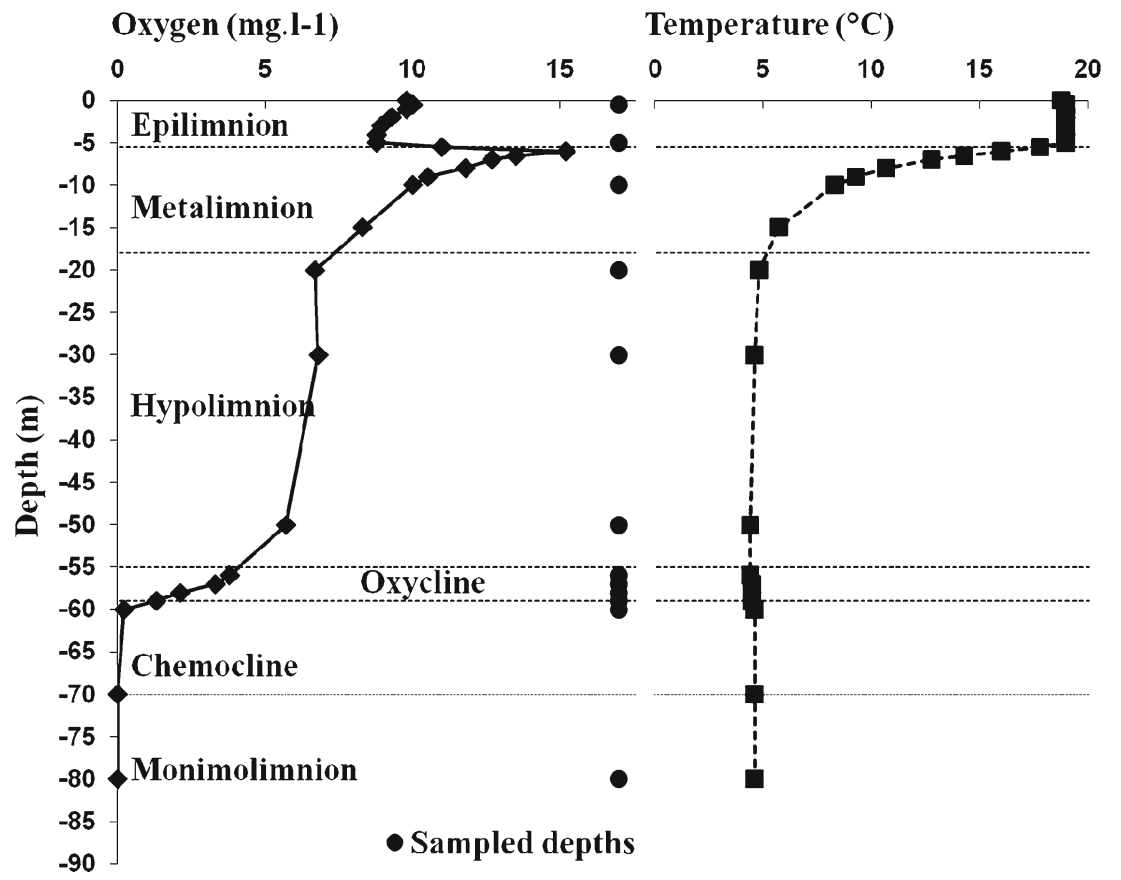


column. This includes the epi- $(0.5$ and $5 \mathrm{~m})$, meta- $(12 \mathrm{~m})$ and hypolimnion $(20,30$ and $50 \mathrm{~m})$ for the mixolimnic layer where almost all studies done to date in Lake Pavin were restricted [5, 6, 34], as well as the oxycline $(56,57,58$, $59 \mathrm{~m})$, the chemocline $(60 \mathrm{~m})$ and the deep monimolimnic $(80 \mathrm{~m})$ layers (Fig. 1). All samples were collected and analysed in triplicates. For suboxic and anoxic layers, live samples were taken and processed (i.e. for prokaryotic production measurements) in sterile serum bottles sealed with rubber and aluminium crimp caps and flushed with $\mathrm{N}_{2}$.

\section{Prokaryotic Production}

Bacterial production (BP) was determined by incorporation of ${ }^{3} \mathrm{H}$ leucine (final concentration, $40 \mathrm{nmol}$; specific activity $=71 \mathrm{Ci} \mathrm{mmol}^{-1}$; Amersham Biosciences, UK) into bacterial biomass using the microcentrifuge method [35]. Incubation time (30 min in situ in the dark) was fixed from preliminary experiments conducted on 25 March 2004 [20], and protein precipitation in controls (i.e. 5\% TCA-killed) and fixed assays was aided by adding $\mathrm{NaCl}$ (final concentration, $3.5 \% v / v)$ at $18^{\circ} \mathrm{C}$ for $30 \mathrm{~min}$. After centrifuge washings, microbial pellets were dissolved in $0.2 \mathrm{~mL}$ $1.2 \mathrm{~N} \mathrm{NaOH}$ at $80^{\circ} \mathrm{C}$ for 20 min and scintillation cocktail (1 mL; Ready Safe, Beckman Coulter) added for radioactivity counting with a Beckman LS 6500 liquid scintillation counter. Leucine incorporation was converted into the number of cells produced by using conversion factors $(0.27 \times$ $10^{18}$ cells mol $^{-1}$ for oxic waters and $0.25 \times 10^{18}$ cells mol $^{-1}$ for suboxic and anoxic waters) determined during the preliminary study [20].

\section{Phage-Infected Bacteria and Burst Size}

For viral lytic infection, the frequency of infected cells (FIC) and the viral-induced bacterial mortality (VIBM) were calculated from the frequency of visibly infected cells (FVIC) obtained from observations under a JEOL 1200EX transmission electron microscope, after ultracentrifugation and uranyl acetate staining. The procedure is detailed elsewhere [6, 47]. For each sample, mean burst size (BS) was estimated from the mean number of viruses in those infected cells which were filled with phages. To estimate VIBM, the FIC was calculated from the FVIC (as a percent) using the formula FIC $=9.524$ FVIC-3.256 [67]. FIC was then converted to VIBM according to [8]: $\mathrm{VIBM}=\left(\mathrm{FIC}+0.6 \mathrm{FIC}^{2}\right) /(1-1.2 \mathrm{FIC})$.

Protistan Bacterivores and Their Potential Activity

Samples for enumeration of nanoflagellates (NF) were fixed immediately after sampling with glutaraldehyde (final concentration, $1 \%$ ). Primulin-stained NF collected on $0.8-\mu \mathrm{m}$ polycarbonate black filters were counted under a Leica DC $300 \mathrm{~F}$ epifluorescence microscope, using two sets of optic filters: UV light for heterotrophic NF (HNF) and blue light for pigmented NF [16]. The abundances of NF taxonomic groups known as typical bacterivores in Lake Pavin [15] were used for the estimations of potential grazing activities from protists. These groups of bacterivores were as follows: choanoflagellates, Monas-like cells and a fraction of undetermined small flagellates (see below) for HNF and Ochromonas spp. for pigmented NF (i.e. mixotrophs). Potential specific grazing rates were estimated as the product of bacterial concentration, the abundance of NF groups of interest and mean specific clearance rates of 3, 6, 7 and $8 \mathrm{~nL}$ flagellate ${ }^{-1} \mathrm{~h}^{-1}$ for undetermined flagellates, Monaslike cells, choanoflagellates and Ochromonas spp., respectively, as previously estimated from a previous seasonal study in Lake Pavin [15]. These clearance rates fell well within the range of values published for freshwater ecosystems [52]. For the group of 'undetermined flagellates', cells with a straight and long single flagellum, typical of nonprotistan chytrid zoospores (i.e. fungi) based on both morphological and molecular characterization (cf. [36]) and known as non-phagotrophs from previous bacterivory experiments in Lake Pavin [15], were excluded from comparisons. These forms represented on average about $25 \%$ of the undetermined HNF. Total potential grazing rates were calculated by adding specific rates.

\section{Other Variables}

The temporal and vertical variations in the water temperature, dissolved oxygen and concentrations of chlorophyll $a$, as well as those in the abundances of viral and microbial communities (i.e. heterotrophic bacteria, picocyanobacteria, autotrophic picoeukaryotes and heterotrophic and autotrophic nanoflagellates), have been described and discussed in detail in a companion paper [21].

\section{Statistical Analysis}

Normal distribution of data was checked by KolmogorovSmirnov test. Because not all the data sets followed normal distribution, we applied log transformation to meet the requirements for parametric statistics. Two-way analysis of variance (ANOVA) was used to test for the effects of seasons (i.e. spring (April to June), summer (July to September) and autumn (October to December)] and depth-related gradients as represented by the different layers sampled (i.e. epi-, meta- and hypolimnion, oxycline, chemocline and monimolimnion). Tukey tests were performed if the result of ANOVA indicated significant interaction between the effects of seasons and of sampling depths. In addition, a matrix of data was produced and analysed by means of 
principal component analysis (PCA) to identify the combination of variables that accounts for the largest amounts of the total variance observed in different layers of the lake, with particular emphasis on viral lytic activity. Potential relationships among variables were tested by Pearson correlation analysis for each sampled layer. All statistical analyses were performed using MINITAB 12 and SYSTAT 10.

\section{Results}

\section{Prokaryotic and Viral Activities}

BP fluctuated from 3.8 to $73.7 \times 10^{6}$ bacteria $\mathrm{L}^{-1} \mathrm{~h}^{-1}$. The lowest values were reported in the hypolimnion and the highest ones from the oxycline downwards (Table 1). However, the effect of depth on BP was not significant, contrasting with the effect of season (Table 2) due to the decrease in BP values from spring to autumn (Fig. 2a).

The FVIC fluctuated from 0 to $3.1 \%$, corresponding to a viral-induced bacterial mortality (FIC) of 0 to $43.2 \%$ of bacterial production. FVIC significantly decreased with depth (Table 2), because mixolimnic values were higher $(>1 \%)$ compared to the deep layers of the lake $(<0.7 \%$, Table 1$)$. The highest FVIC occurred in October in the epilimnion and in April in the hypolimnion (Fig. 2b), but the effect of season was not significant (Table 2). Because ANOVA revealed a significant interaction between depth and season, we applied the post hoc Tukey test which showed a clear difference $(p<0.001)$ between mixolimnic and monimolimnic layers for FVIC. Infected cells contained between 7 and 127 viruses per bacteria, with an overall mean BS of 31 viruses per bacteria. The effects of depth and season on BS were significant and independent, with the highest values in the mixolimnion, primarily during spring (Fig. 2c, Tables 1 and 2).

\section{Potential Protistan Bacterivory}

The abundance of nanoflagellates considered as bacterivores fluctuated from 0 to $1.5 \times 10^{3}$ cells $\mathrm{mL}^{-1}$, corresponding to 0 to $60 \times 10^{6}$ bacterial cells ingested per litre per hour (Fig. 2d). Protistan bacterivory was largely dominated by the group of 'undetermined grazers' which represented 50 to $85 \%$ of the total grazing rate, followed by Monas-like cells $(10-40 \%)$ and by Ochromonas spp. and choanoflagellates $(<20 \%)$. Seasonal differences in potential grazing were significant (Table 2), and different groups of grazers dominated the total grazing during the different seasons. Indeed, the groups of 'undetermined grazers', Ochromonas spp. and choanoflagellates, were most active in summer, while Monas-like cells dominated the bacterivory in spring. In autumn, the activity from choanoflagellates was the highest (data not shown). Almost all grazers were restricted in the surface waters, i.e. in the mixolimnion (Table 1), and the effect of depth was also significant (Table 2). In all sampled depths, the bacterial mortality due to grazers was on average one order of magnitude higher than that derived from viral lysis (Table 1).

\section{Correlations and PCA}

According to depth layers, $80 \%$ of the total number of significant correlation coefficients between FVIC and other biological variables of interest were calculated in the deep layers of the lake, from the hypolimnion downwards. FVIC was correlated with bacterial abundance in the hypolimnion and in the oxycline, and with bacterial production in the oxycline, chemocline and monimolimnion. These correlations with bacterial variables were negatives in the oxycline but positives in the other layers. FVIC was also positively correlated with burst size in the hypolimnion, oxycline and

Table 1 Mean values (coefficient of variation) for each depth sampled in Lake Pavin from April to December of 2005

\begin{tabular}{|c|c|c|c|c|c|c|c|c|c|}
\hline Layer & Depth & $\begin{array}{l}\text { Chl.a } \\
\left(\mu \mathrm{g} \mathrm{L}^{-1}\right)\end{array}$ & $\begin{array}{l}\text { BA } \\
\left(10^{6} \text { bacteria } L^{-1}\right)\end{array}$ & $\begin{array}{l}\text { BP } \\
\left(10^{6} \text { bacteria } \mathrm{L}^{-1} \mathrm{~h}^{-1}\right)\end{array}$ & $\begin{array}{l}\text { FVIC } \\
(\%)\end{array}$ & $\begin{array}{l}\text { Mean } \\
\text { BS }\end{array}$ & $\begin{array}{l}\text { Grazing total } \\
\left(10^{6} \text { bacteria } \mathrm{L}^{-1} \mathrm{~h}^{-1}\right)\end{array}$ & $\begin{array}{l}\text { Viral lysis } \\
(\% \mathrm{BP})\end{array}$ & $\begin{array}{l}\text { Grazing } \\
(\% \mathrm{BP})\end{array}$ \\
\hline \multirow[t]{2}{*}{$\mathrm{E}$} & -0.5 & $2.1(86)$ & $5.7(24)$ & $22.6(52)$ & $1.1(78)$ & $30.1(52)$ & $18.8(56)$ & $10.1(135)$ & $99.6(71)$ \\
\hline & -5 & $2.2(77)$ & $6.1(34)$ & $17.8(62)$ & $1.3(56)$ & $31.1(38)$ & $16.5(55)$ & $11.6(91)$ & $115.0(73)$ \\
\hline M & -10 & $3.4(108)$ & $8.3(73)$ & $21.0(74)$ & $1.1(47)$ & 36.7 (74) & $22.4(80)$ & $9.1(69)$ & $141.8(96)$ \\
\hline \multirow[t]{3}{*}{$\mathrm{H}$} & -20 & $5.0(76)$ & $5.7(34)$ & $19.6(68)$ & $1.3(47)$ & $40.1(42)$ & $15.5(51)$ & $11.6(85)$ & $119.4(64)$ \\
\hline & -30 & $3.5(59)$ & $4.4(36)$ & $16.8(68)$ & $1.1(52)$ & $54.3(77)$ & $9.2(110)$ & $8.9(83)$ & $66.0(76)$ \\
\hline & -50 & $1.4(118)$ & $3.2(38)$ & $18.9(84)$ & $0.7(62)$ & $32.7(60)$ & $3.9(72)$ & 3.9 (99) & $31.8(93)$ \\
\hline \multirow[t]{4}{*}{$\mathrm{O}$} & -56 & $1.4(126)$ & $3.1(37)$ & $20.7(96)$ & 0.7 (79) & $29.6(52)$ & $4.0(70)$ & 4.8 (143) & $26.8(61)$ \\
\hline & -57 & $1.3(123)$ & $3.9(33)$ & 22.3 (99) & $0.6(77)$ & $30.1(41)$ & $5.5(89)$ & $3.7(162)$ & $31.5(95)$ \\
\hline & -58 & $1.0(136)$ & $4.9(53)$ & $23.5(92)$ & $0.5(29)$ & $24.6(69)$ & $5.8(64)$ & $1.8(79)$ & $30.8(54)$ \\
\hline & -59 & $0.7(105)$ & $5.6(42)$ & $23.0(92)$ & $0.6(87)$ & $21.5(39)$ & $3.1(81)$ & $3.2(153)$ & $17.8(53)$ \\
\hline $\mathrm{C}$ & -60 & $1.0(153)$ & $7.2(30)$ & $22.5(89)$ & $0.4(56)$ & $15.7(49)$ & $4.6(122)$ & $1.5(113)$ & $40.2(176)$ \\
\hline Mo & -80 & $0.3(481)$ & $14.3(47)$ & $21.7(83)$ & $0.5(90)$ & $22.5(39)$ & $1.0(184)$ & $2.7(115)$ & $16.1(254)$ \\
\hline
\end{tabular}

Chl. $a$ chlorophyll $a, B A$ bacterial abundance, $B P$ bacterial production, FVIC frequency of visibly infected cells, $B S$ burst size, $E$ epilimnion, $M$ metalimnion, $H$ hypolimnion, $O$ oxycline, $C$ chemocline, $M o$ monimolimnion 
Figure 2 Seasonal variations of prokaryotic production (a), frequency of visibly infected cells (b), burst size (c) and estimate of total grazing (d) in the water column of Lake Pavin
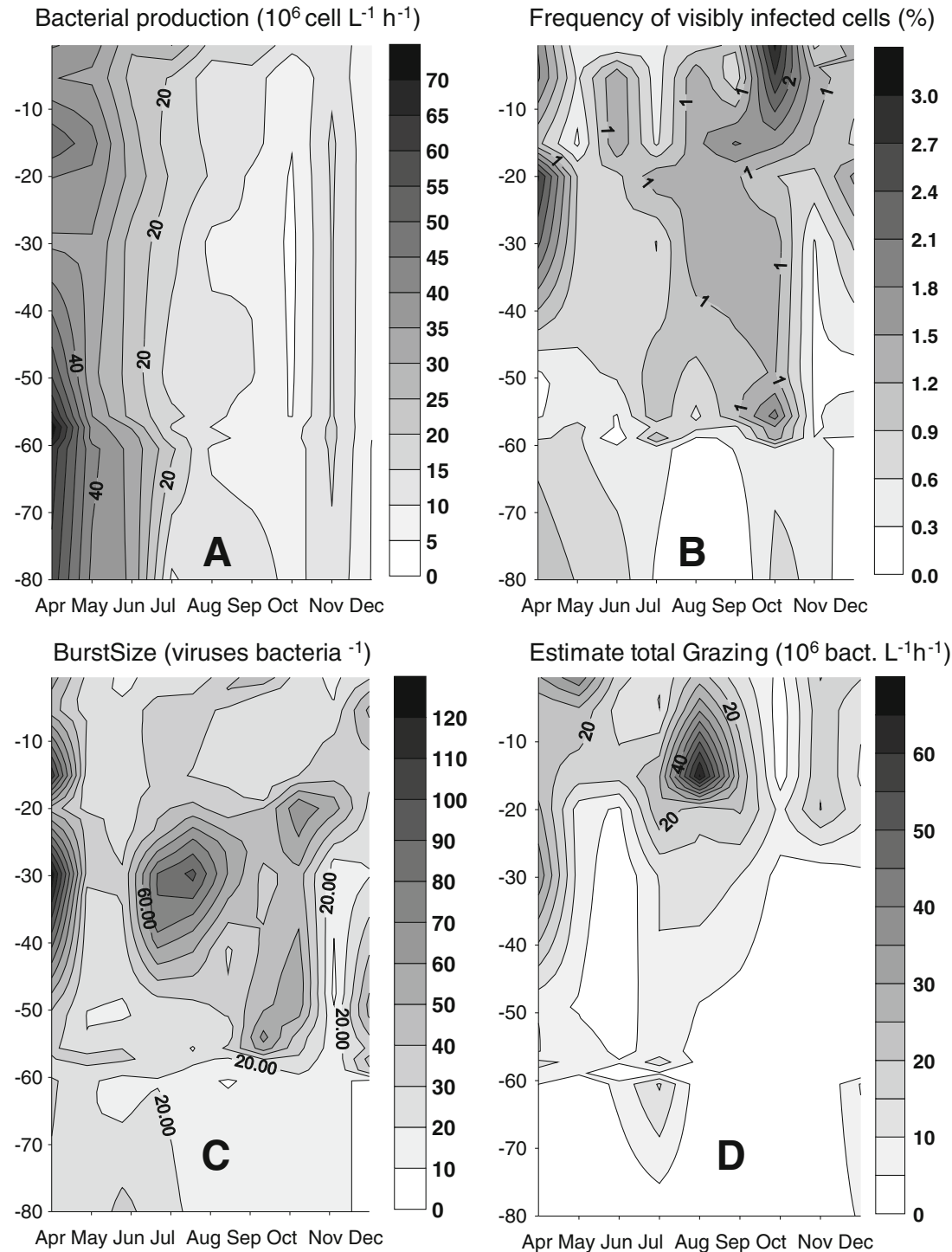

chemocline and similarly with the abundance of potential bacterivores and with chlorophyll $a$ concentration in the hypolimnion (Table 3).
The plot of field observations from PCA showed that the seasonal distributions of variables under study were dependent to the vertical gradients. According to the locations of

Table 2 Two-way ANOVA results for effects of season and layer on biological variable counts

\begin{tabular}{|c|c|c|c|c|c|c|c|c|}
\hline & \multicolumn{8}{|c|}{ ANOVA value for } \\
\hline & \multicolumn{2}{|l|}{$\mathrm{BP}$} & \multicolumn{2}{|l|}{ FVIC } & \multicolumn{2}{|c|}{ Mean BS } & \multicolumn{2}{|l|}{ GT } \\
\hline & $F$ & $P$ & $F$ & $P$ & $F$ & $P$ & $F$ & $P$ \\
\hline $\mathrm{S}$ & 98.947 & $<0.0001$ & 2.591 & 0.077 & 4.145 & 0.017 & 3.652 & 0.027 \\
\hline $\mathrm{L}$ & 0.381 & 0.861 & 21.686 & $<0.0001$ & 9.889 & $<0.0001$ & 81.030 & $<0.0001$ \\
\hline Interaction (SL) & 0.846 & 0.586 & 6.777 & $<0.0001$ & 1.272 & 0.245 & 1.897 & 0.060 \\
\hline
\end{tabular}

Data are from samples obtained from April to December of 2005. Degrees of freedom are 2, 5, 10 and 306 for S, L, SL and error, respectively, except for mean BS for which degrees of freedom are 2, 5, 10 and 294

$B P$ bacterial production, $F V I C$ frequency of visibly infected cells, $B S$ burst size, $G T$ grazing total, $F F$ ratio, $P$ probability, $S$ season, $L$ layer 
Table 3 Results of Pearson correlation analysis used to test for correspondence between temporal changes in the FVIC and the other estimated variables in six different depth layers of Lake Pavin

\begin{tabular}{|c|c|c|c|c|c|c|}
\hline FVIC vs: & E & M & $\mathrm{H}$ & $\mathrm{O}$ & $\mathrm{C}$ & Mo \\
\hline Bacterial abundance & & & 0.44 & -0.35 & & \\
\hline Bacterial production & & & & -0.34 & 0.78 & 0.71 \\
\hline Burst size & & & 0.43 & 0.41 & 0.91 & \\
\hline Bacterivores & & & 0.51 & & & \\
\hline Chloropyll $a$ & & & 0.47 & & & \\
\hline
\end{tabular}

The number of degrees of freedom depends on the number of depths sampled per layer, in triplicates for biological variables. Only significant correlations are given (blanks mean not significant), $p<0.001$

the different depth-related layers along the two major axes of this plot, we distinguished three groups of two layers each along the water column: surface (epi- and metalimnion), intermediate (hypolimnion and oxycline) and deep (chemocline and monimolimnion) water masses (Fig. 3a). Because of the overlaps between consecutive groups of water masses, our distinction was somewhat arbitrary but clearly related to distinct physico-chemical characteristics: oxygenated with fluctuating temperature for the surface waters, oxygenated with constant temperature at $4^{\circ} \mathrm{C}$ for the intermediate layer and permanently anoxic for the deep layer. In the related plots of the descriptors, the depicted axes 1 and 2 explained about $50-65 \%$ of the total variance, and FVIC was located in between the negative ends of the two axes in all plots. However, the associated variables differed markedly from one plot to another, with bacterial production rotating from the extreme positive end of axis 1 in surface waters (Fig. 3b) to the extreme positive end of axis 2 in intermediate waters (Fig. 3c), before closely approaching the FVIC position in the deepest waters (Fig. 3d). Major explaining variables for FVIC mainly included viral abundance in the surface waters, burst size and grazers in the intermediate waters, and burst size and bacterial production in the deepest waters.

\section{Discussion}

\section{General Considerations}

In this study, we analysed the seasonal changes in virusinduced mortality of prokaryotes together with the potential bacterivory from heterotrophic nanoflagellates in the deep meromictic Lake Pavin. For the first time, our study included the whole water column of the lake and all seasons of the year. Previous studies of the biological limnology $[15,16,36,38]$ and on viral ecology $[5,6]$ of Lake Pavin were restricted to the mixolimnion, above $40 \mathrm{~m}$ depth, ignoring the deep layers which contain about half of the total volume of water in the lake. In the mixolimnic layers, Bettarel and co-authors [6] demonstrated strong seasonal variability but no depthrelated difference in viral abundance and lytic activity, and found that the removal of bacterial production by flagellate grazing was nearly always higher than the production removed by viral lysis. Such data are lacking for the deep layers of Lake Pavin which exhibit physicochemical characteristics that are fundamentally different from those of the mixolimnion [1].

\section{Viral Infectivity and the Depth-Related Variability}

The Frequency of Visibly Infected Cells We have used the whole cell method for the determination of FVIC. This approach has been submitted to critics and can yield estimates with relatively large errors [6]. For example, at least 400 bacterial cells were inspected per grid during the present study, for a number of visibly infected cells between 0 and 30 cells. However, our FVIC levels (i.e. 0-3.1\%) were within the typical range (i.e. $<5 \%$ ) reported in pelagic systems using the same methodological approach [70]. In Bettarel et al. [6], mixolimninic FVIC varied between 0.3 and $4.1 \%$ and peaked at $10 \mathrm{~m}$ in spring and at 5 and $35 \mathrm{~m}$ in autumn but with no significant differences between the three sampled depths. This differed from the findings in the present study where the effects of depth layers but not of seasons on FVIC were significant, although the FVIC range $(<3.1 \%)$ was relatively narrower than that $(<4.1 \%)$ reported by Bettarel and co-authors [6]. This comparison indicates an apparent mismatch in the seasonal and depth-related variability of viral infectivity in Lake Pavin between the two studies, which can be related to interannual differences in viral proliferation or to differences in sampling strategies adopted in the two studies.

The latter explanation is most likely because for each sampling time, the coefficients of variations around FVIC mean values in this study (range, 40-81\%) were largely higher than those $(<25 \%)$ in Bettarel et al. [6], due to the sharp decrease in FVIC with depths in the present study. This is further strengthened by the facts that the seasonal depth-related patterns reported in Bettarel et al. [6] in the mixolimnion of Lake Pavin, particularly the peaks noted in spring and autumn, were also found in the present study and in other lakes as well (cf. [6]). Furthermore, FVIC values in this study were relatively lower in the subsurface waters at $0.5 \mathrm{~m}$ depth, primarily during spring and summer times (Fig. 2b), corroborating the hypothesis on UV-induced inactivation of surface viruses that is also discussed in Bettarel et al. [6], based on supporting literature in the context of world aquatic ecosystems (e.g. [28, 32, 41, 59]). The above comparisons thus clearly highlight the importance of the deepest layers in viral activity and ecology, and the related processes in deep lake ecosystems such as Lake Pavin. 

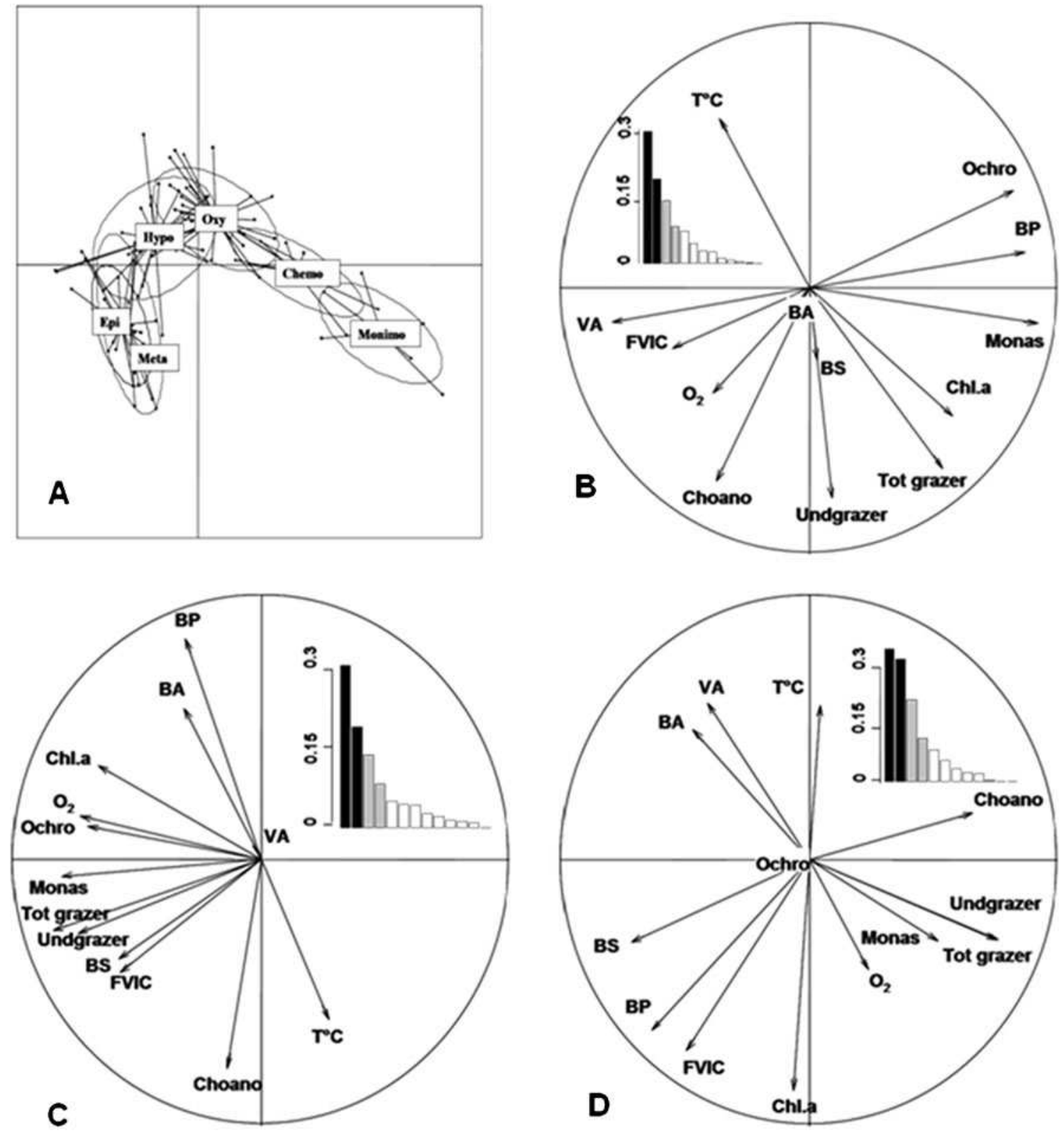

Figure 3 Results of the principal component analysis obtained from the observations made for each of the six sampling depth layers (a) and from the main variables under study in three groups of these depth layers: epi- and metalimnion combined (b), hypolimnion and oxycline combined (c) and chemocline and monimolimnion combined (d). Abbreviations are as follows: temperature $\left(T^{\circ} \mathrm{C}\right)$, oxygen concentration $\left(\mathrm{O}_{2}\right)$, chlorophyll $a$ concentration (Chl.a), the abundances of viruses $(V A)$, bacteria $(B A)$, potential bacterivores (Tot grazer) and the related

Burst Size The mean numbers of intracellular viruses observed per infected bacterial cell in the present study (range, 7-127; median value $=67$ ) were apparently higher compared to those (range, $10-55$; median value $=32$ ) reported in the mixolimnic study by Bettarel et al. [6]. However, the overall mean BS in both studies was more comparable than the range and median values, with a substantially higher coefficient of variation around the mean in the present study

taxonomic groups [Monas-like cells (Monas), choanoflagellates (Choano), Ochromonas (Ochro) and undetermined grazers (undgrazer)], bacterial production $(B P)$, burst size $(B S)$ and the frequency of visibly infected cells $(F V I C)$. Horizontal $x$-axis $=$ axis 1 , vertical $y$-axis $=$ axis 2 . Inset histograms in $\mathbf{b}$ - $\mathbf{d}$ represent fractions of variance $(Y$, in percent) which are explained by the different PCA axes (x, from axis 1 onwards)

(mean $\pm \mathrm{CV}=31 \pm 58$ ) than in Bettarel and co-authors [6] where seasonal BS were about constant (mean $\pm \mathrm{CV}=25 \pm 4$ ). This was clearly due to the inclusion of the deepest waters in the present study where BS were significantly (ANOVA, $p<0.001)$ lower than in the mixolimnic waters. No clear seasonal patterns occurred in both studies, corroborating similar results reported in Lake Mono where BS varied from 10 to 55 viruses per bacteria [14]. Our findings on the spatial 
variability of viruses in Lake Pavin contrast with reports [65, 68] where BS were higher in the anoxic waters than in the surface waters of Lake Plu $\beta$ see and of the Baltic Sea, respectively. Unexpectedly, the general occurrence of higher BS in the surface than in the deep waters of Lake Pavin also contrasted with the vertical pattern in bacterial production which was, on average, higher in deep than in surface waters. This seems unreasonable because BS is related to bacterial cell biovolume $[31,64,66]$, and both variables are known to increase with increasing bacterial growth rate [40]. As previously given [6], this assumption is realistic only if the viral populations have about the same capsid size.

As previously shown in a preliminary study in Lake Pavin [20], the present study confirms the substantial changes in the morphometric diversity of pelagic viruses in relation to the depth-related gradients. Indeed, viral communities in the permanently anoxic monimolimnion of Lake Pavin comprised a substantial number of atypical bacteriophage forms, larger in capsid size $(>60 \mathrm{~nm})$, and with more complex spatial conformation (Fig. 4), compared to the mixolimnic viruses which were more typical of the world aquatic free-occurring bacteriophages dominated by small (capsid size $<60 \mathrm{~nm}$ ) Siphoviridae, Podoviridae and Myoviridae [56]. In addition, an analysis of viral diversity based on the distribution frequency of capsid sizes through the whole water column of Lake Pavin has indicated that viruses were apparently typical and more diversified in the monimolimnion than in the surface waters, although the study was based on one-date sampling (see Fig. 2a in [20]). This finding corroborates a recent study in Lake Pavin which has unveiled a complete shift in the composition of the prokaryotic assemblages between the mixolimnion and the monimolimnion, with a maximal Archaea/Eubacteria ratio that reached below mixolimnic layers [37]. Because prokaryotic specific cell volume is similar through the water column at about $0.1 \mu^{3}$ [54], it is thus likely that deep anoxic viruses in Lake Pavin include endemic, typical populations, with different morphometry and diversity characteristics
Figure 4 Surface and deep water viruses are apparently different in Lake Pavin: overview of the general morphotypes of viruses in the water column, including the characteristic free-occurring pelagic forms [Siphoviridae (a), Podoviridae (b), Myoviridae (c) and untailed phages (d)], which are dominant, primarily in the mixolimnion, and the more atypical forms or complex spatial arrangement/conformation (e) which occurred mainly in the permanently deep anoxic waters
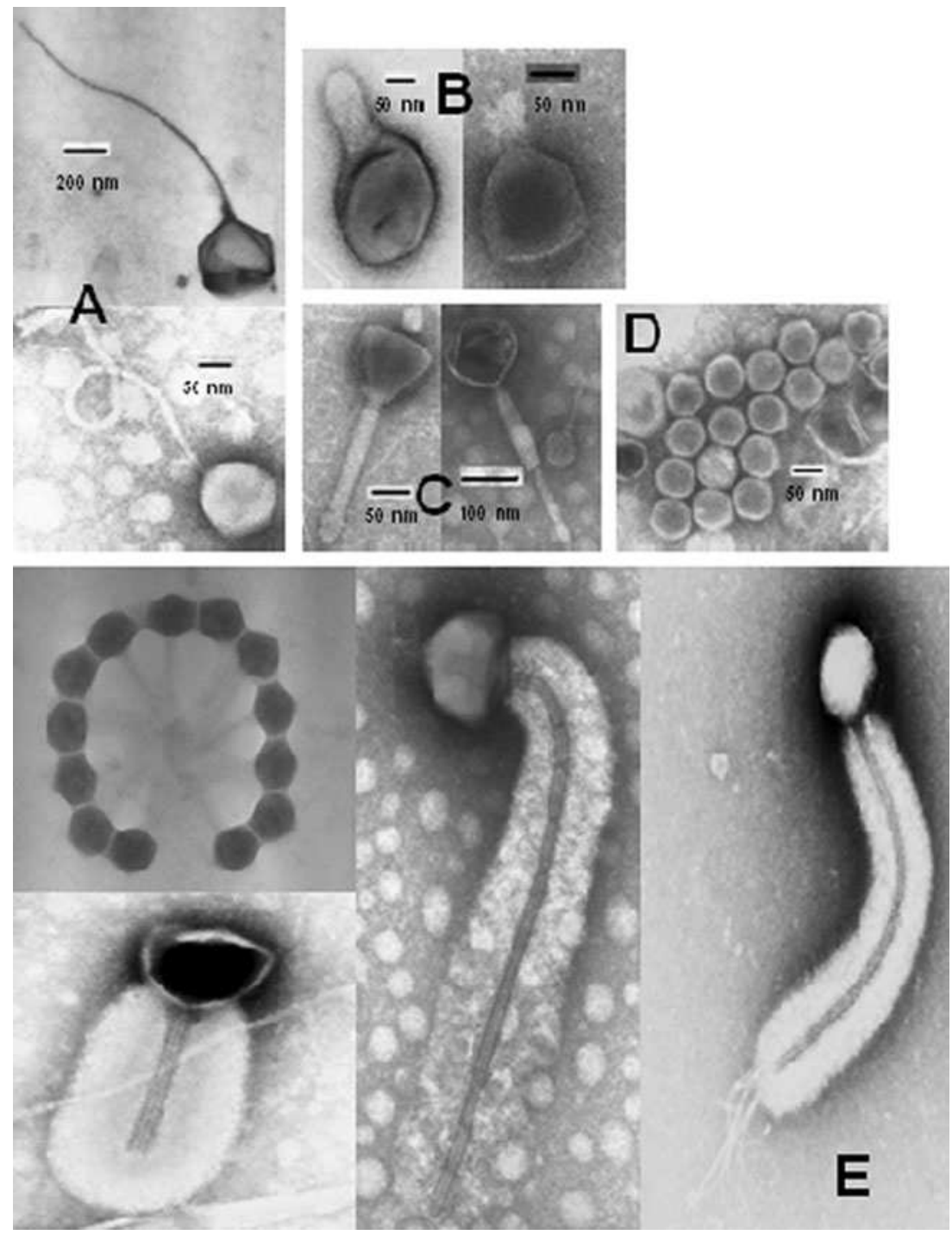
compared to surface water viruses. The potential viral infection of Archaea which are abundant in the monimolimnion of Lake Pavin [37] could also explain observed depthrelated changes in viral morphology. This may help explain why burst sizes in this lake decreased significantly in the deep layers and further stresses the ecological importance of these layers.

Empirical Forcing of Depth-Related Gradients in Viral Lytic Activity

In a companion paper analysing the seasonal and spatial abundances of viruses, multivariate and correlative statistical analyses suggested an apparent shift in the viral interactions with various autotrophic and heterotrophic microbial components between the mixo- and the monimolimnion of Lake Pavin. In this paper, viruses were correlated mainly with microautotrophs in the mixolimnion but exclusively with heterotrophic prokaryotes in the monimolimnion where the other microbial communities were apparently constrained by the dark anoxic conditions [21]. In the present paper and based on the same type of analyses, the differential responses of lytic viruses to the depth-related gradients were confirmed. Indeed, assuming that BS and the FVIC within prokaryotic communities reflected the lytic activity of viruses, the results of correlation and PCA have highlighted the ecological importance of deep waters in the context of aquatic viral ecology.

Indeed, almost all significant correlations with BS and FVIC occurred from the hypolimnion downwards, implying mainly prokaryotic variables (abundance, production) as dominant correlates. The relative importance of bacterial production in explaining variance in BS and FVIC increased with depth, and prokaryotic variables were exclusive correlates for FVIC and BS from the oxycline downwards. All correlations were positives, at the exception of those between FVIC and prokaryotic variables in the oxycline (Table 3, Fig. 3). This corroborates the hypothesis that this layer is a key transitive microhabitat in Lake Pavin, where the complex mixolimnic biological communities and the related interactions are replaced by a simple viral loop system [i.e. dissolved organic matter $(\mathrm{DOM})>$ prokaryote $>$ viruses $>\mathrm{DOM}]$ towards the dark and permanently anoxic monimolimnion [20, 21]. In general, the oxycline/chemocline layer in Lake Pavin is well known as an important barrier, characterized by particular geochemical properties, that acts as a key interface in the vertical flow and recycling of matter through the water column [1]. The increase of Archaea and Eubacteria abundances reported in this layer corresponds to a complete shift in the composition of prokaryotic assemblage [37]. Combined with the absence of grazers [20], this could stimulate the development of specific viral communities.
The mean seasonal FVIC decreased with increasing depth, while the mean seasonal values for prokaryotic host production increased with depth. In terms of abundances, viruses and bacteria peaked not only in the metalimnion but also in the monimolimnion [21], a pattern that somewhat also contrasted with that in FVIC. This was unexpected from the literature data $[44,47,57]$ and from the singledate preliminary study conducted in Lake Pavin where viruses and prokaryotes increased with depth in terms of both abundance and activity [20]. The above comparison implies that, at a seasonal scale, viral proliferation as estimated from the FVIC method in the deepest layers was at its lower potential and does not fully exploit the abundant and rapidly renewing ambient host resources. Otherwise, a part of the free-occurring abundant viruses in these layers were not lytically infective for their ambient hosts, and the fate of free viruses through grazing was unlikely because of the general absence of grazers in the monimolimnion (Fig. 2d). A similar finding was recently reported and termed 'infection paradox', as a typical feature of freshwater benthic viruses, but the mechanisms behind are unknown [25].

In this study, the discrepancy between high seasonal viral abundance and low FVIC in the deepest planktonic layers of Lake Pavin also appeared difficult to be reconciled. We have shown that some of the deep viruses in Lake Pavin are typical, and there is a probability of the coexistence of different styles of viral proliferation, including chronic, lysogenic or pseudolysogenic production. Evoking inputs of viruses from the surface waters and/or from the sediments is also tempting, although (1) oxycline and chemocline are strong barriers for surface vs deep vertical exchanges within the lake, (2) the monimolimnion is considered as a physically stable and steady-state environment [1] and (3) it is where viruses are likely typically different from those in the surface water [20]. Because free viruses can maintain their physical integrity and even their infectivity for a long time, up to several tens of years [58], it is also likely that a pool of 'long-lived' allochthonous viruses may cohabit with the endemic typical deep viruses which depend on the ambient bacterial production. It has been shown that viruses in deep, cold marine waters exhibit a particularly low decay rate [43], and this may be the case for the so-called 'long-lived' deep viruses. Greater resistance to infection due to low temperature-mediated modifications of viral receptors on the host membrane or of intracellular defence responses can also be prevalent in deep cold waters [10]. It is indeed rational that short host generation times promote rapid evolution of phage resistance. A number of plausible reasons could thus account with the observed high abundances of viruses and prokaryotes concomitant with high prokaryotic production but with low lytic activity of viruses in the deepest waters of Lake Pavin. 
Compared to the previous studies in Lake Pavin and with other sites where no correlation has been observed between viruses and $\mathrm{HNF}$ considered as the main grazers of pelagic prokaryotes (cf. [6, 21]), FVIC in the present study was significantly correlated to the potential bacterivory from those protists previously shown to ingest bacteria [15] in the hypolimnion where the peaks in FVIC coincided with peaks in Monas-like bacterivores in spring and in the other groups of bacterivores in summer. Activities from the different groups of grazers, together with burst size, indeed appeared as strong explaining factors for the seasonal variability in FVIC recorded in the hypolimnion/oxycline intermediate layer (Fig. 3). We now know that HNF assemblages in pelagic ecosystems comprise non-bacterivorous species such as fungal zoospores [36]. In the present study, the interference from these non-bacterivores was minimized by targeting specific groups or taxa known as strict bacterivores or mixotrophs [15]. The approach probably has contributed to the observed correlation between FVIC and the calculated potential bacterivory. It is well known that there are many routes of interactions between viruses and grazers. This has been widely tested from experimental studies (cf. [46] and references therein) but only partially from empirical and trophodynamic seasonal data (cf. [5]).

\section{Conclusions}

This study presents an original depth-related survey of virioplankton lytic activity in relation to bacterial production and potential protistan bacterivory in a volcanic deep lake, complimenting a companion paper on the abundances and vertical community structure of viruses and microorganisms [21]. The sampling strategy adopted, with 12 different depths sampled through the 92-m-deep water column, was considered representative of the whole water column of Lake Pavin and the related physico-chemical gradients. Compared to previous studies known from the mixolimnic layers in the same lake, the main findings have highlighted the importance of the deepest layers in viral activity and ecology, and the related processes in deep freshwater ecosystems such as Lake Pavin. Deep waters indeed appeared as an exclusive environment for heterotrophic prokaryotes, whose seasonal activity offers an optimal and unique resource for thriving viral communities, some of which may be typical, endemic to the ambient dark, cold and stable deep water masses. The exclusive seasonal coupling between viruses and prokaryotes was not obvious from the sole depth-related gradients, because high abundances of viruses and prokaryotes concomitant with high prokaryotic production but with low lytic activity of viruses occurred in the deepest waters of the lake. Overall, the main findings on the functional responses of viruses and prokaryotes to depth get well around a previous statement that the ecology of the deepest waters of Lake Pavin is essentially driven by the dark viral loop (DOM-prokaryotes-viruses) processes, which can sequester organic matters and nutrients for a long-lived turnover time $[20,21]$. This is in agreement with findings from marine systems showing that mesoand bathypelagic waters are optimal environments for viral survival and proliferation in the North Atlantic [43] and Mediterranean Seas [39].

Acknowledgments JC was supported by a Ph.D. Fellowship from the Grand Duché du Luxembourg (Ministry of Culture, High School, and Research). The study was partly supported by the French National Program ACI/FNS "ECCO" (VIRULAC research grant awarded to TSN, coordinator) and by the French ANR Program "Biodiversité" (AQUAPHAGE research grant to TSN, PI).

\section{References}

1. Aeschbach-Hertig W, Hofer M, Schmid M, Kipfer R, Imboden DM (2002) The physical structure and dynamics of a deep, meromictic crater lake (Lac Pavin, France). Hydrobiologia 487:111136

2. Almeida MA, Cunha MA, Alcantara F (2001) Loss of estuarine bacteria by viral infection and predation in microcosm conditions. Microb Ecol 42:562-571

3. Azam F, Fenchel T, Field JG, Gray JS, Meyer-Reil LA, Thingstad F (1983) The ecological role of water-column microbes in the sea. Mar Ecol Prog Ser 10:257-263

4. Bergh Ø, Børsheim KY, Bratbak G, Heldal M (1989) High abundance of viruses found in aquatic environments. Nature 340:467468

5. Bettarel Y, Amblard C, Sime-Ngando T, Carrias JF, Sargos D, Garabetian F, Lavandier P (2003) Viral lysis, flagellate grazing potential, and bacterial production in Lake Pavin. Microb Ecol 45:119-127

6. Bettarel Y, Sime-Ngando T, Amblard C, Dolan J (2004) Viral activity in two contrasting lake ecosystems. Appl Environ Microbiol 70:2941-2951

7. Billen G, Servais P, Becquevort S (1990) Dynamics of bacterioplankton in oligotrophic and eutrophic aquatic environments: bottom-up or top-down control? Hydrobiologia 207:37-42

8. Binder B (1999) Reconsidering the relationship between virally induced bacterial mortality and frequency of infected cells. Aquat Microb Ecol 18:207-215

9. Bird DF, Kalff J (1984) Empirical relationships between bacterial abundance and chlorophyll concentration in fresh and marine waters. Can J Fish Aquat Sci 41:1015-1023

10. Bohannan BJM, Lenski RE (2000) The relative importance of competition and predation varies with productivity in a model community. Am Nat 156:329-340

11. Bonilla-Findji O, Herndl GJ, Gattuso JP, Weinbauer MG (2009) Viral and flagellate control of prokaryotic production and community structure in offshore Mediterranean waters. Appl Environ Microbiol 75:4801-4812

12. Boras JA, Sala MM, Vazquez-Dominguez E, Weinbauer MG, Vaqué D (2009) Annual changes of bacterial mortality due to viruses and protists in an oligotrophic coastal environment (NW Mediterranean). Environ Microbiol 11:1181-1193 
13. Bratbak G, Heldal M, Thingstad TF, Riemann B, Haslund OH (1992) Incorporation of viruses into the budget of microbial C-transfer. A first approach. Mar Ecol Prog Ser 83:273-280

14. Brum JR, Steward GF, Jiang SC, Jellison R (2005) Spatial and temporal variability of prokaryotes, viruses, and viral infections of prokaryotes in an alkaline, hypersaline lake. Aquat Microb Ecol $41: 247-260$

15. Carrias JF, Amblard C, Bourdier G (1996) Protistan bacterivory in an oligomesotrophic lake: importance of attached ciliates and flagellates. Microb Ecol 31:249-268

16. Carrias JF, Amblard C, Quiblier-Lloberas C, Bourdier G (1998) Seasonal dynamics of free and attached heterotrophic nanoflagellates in an oligomesotrophic lake. Freshw Biol 39:101-111

17. Carrick HJ, Fahnenstiel GL, Stoermer EF, Wetzel RG (1991) The importance of zooplankton-protozoan trophic couplings in Lake Michigan. Limnol Oceanogr 36:1135-1145

18. Choi DH, Hwang CY, Cho BC (2003) Comparison of virus- and bacterivory-induced bacterial mortality in the eutrophic Masan Bay, Korea. Aquat Microb Ecol 30:117-125

19. Cole JJ, Findlay S, Pace ML (1988) Bacterial production in fresh and saltwater acosystems: a cross-system overview. Mar Ecol Prog Ser 43:1-10

20. Colombet J, Sime-Ngando T, Cauchie HM, Fonty G, Hoffman L, Demeure G (2006) Depth-related gradients of viral activity in Lake Pavin. Appl Environ Microbiol 72:4440-4445

21. Colombet J, Cauchie HM, Portelli C, Sime-Ngando T (2009) Seasonal depth-related gradients in virioplankton: standing stocks and relationships with microbial communities in Lake Pavin (France). Microb Ecol 58:728-736

22. Dolan JR, Gallegos CL (1991) Trophic couplings of rotifers, microflagellates, and bacteria during fall months in the Rhode River Estuary. Mar Ecol Prog Ser 77:147-156

23. Ducklow HW, Carlson CA (1992) Oceanic bacterial production. Adv Microb Ecol 12:113-181

24. Fenchel T (1982) Ecology of heterotrophic microflagellates. IV. Quantitative occurrence and importance as bacterial consumers. Mar Ecol Prog Ser 9:35-42

25. Filippini M, Buesing N, Bettarel Y, Sime-Ngando T, Gessner MO (2006) Infection paradox: high abundance but low impact of freshwater benthic viruses. Appl Environ Microbiol 72:48934898

26. Fisher UR, Velimirov B (2002) High control of bacterial production by viruses in a eutrophic Oxbow lake. Aquat Microb Ecol 27:1-12

27. Fuhrman JA, Noble RT (1995) Viruses and protists cause similar bacterial mortality in coastal seawater. Limnol Oceanogr 40:12361242

28. Garza DR, Suttle CA (1998) The effect of cyanophages on the mortality of Synechococcus spp. and selection for UV resistant viral communities. Microb Ecol 36:281-292

29. Guixa-Boixereu N, Calderón-Paz JI, Heldal M, Bratbak G, Pedrós-Alió C (1996) Viral lysis and bacterivory as prokaryotic loss factors along a salinity gradient. Aquat Microb Ecol $11: 215-227$

30. Guixa-Boixereu N, Lysnes K, Pedrós-Alió C (1999) Viral lysis and bacterivory during a phytoplankton bloom in a coastal water microcosm. Appl Environ Microbiol 65:1949-1958

31. Hennes KP, Simon M (1995) Significance of bacteriophages for controlling bacterioplankton growth in a mesotrophic lake. Appl Environ Microbiol 61:333-340

32. Hofer JS, Sommaruga R (2001) Seasonal dynamics of viruses in an alpine lake: importance of filamentous forms. Aquat Microb Ecol 26:1-11

33. Jacquet S, Domaizon I, Personnic S, Pradeep Ram AS, Heldal M, Duhamel S, Sime-Ngando T (2005) Estimates of protozoan- and viral- mediated mortality of bacterioplankton in Lake Bourget (France). Freshw Biol 50:627-645
34. Jardillier L, Bettarel Y, Richardot M, Bardot C, Amblard C, SimeNgando T, Debroas D (2005) Effects of viruses and predators on prokaryotic community composition. Microb Ecol 50:557-569

35. Kirschner AKT, Velimirov B (1999) Modification of the H-leucine centrifugation method for determining bacterial protein synthesis in freshwater samples. Aquat Microb Ecol 17:201-206

36. Lefèvre E, Bardot C, Noel C, Carrias JF, Viscogliosi E, Amblard C, Sime-Ngando T (2007) Unveiling fungal zooflagellates as members of freshwater picoeukaryotes: evidence from a molecular diversity study in a deep meromictic lake. Environ Microbiol 9:61-71

37. Lehours AC, Bardot C, Thenot A, Debroas D, Fonty G (2005) Anaerobic microbial communities in lake Pavin, a unique meromictic lake in France. Appl Environ Microbiol 71:7389-7400

38. Lepère C, Boucher D, Jardillier L, Domaizon I, Debroas D (2006) Succession and regulation factors of small eukaryote community composition in a lacustrine ecosystem (Lake Pavin). Appl Environ Microbiol 72:2971-2981

39. Magagnini M, Corinaldesi C, Monticelli LS, De Domenico E, Danovaro R (2007) Viral abundance and distribution in mesopelagic and bathypelagic waters of the Mediterranean Sea. Deep-Sea Res I 54:1209-1220

40. Middelboe M (2000) Bacterial growth rate and marine virus-host dynamics. Microb Ecol 40:114-124

41. Noble RT, Fuhrman JA (1997) Virus decay and its causes in coastal water. Appl Environ Microbiol 63:77-83

42. Ory P, Hartmann HJ, Jude F, Dupuy C, Del Amo Y, Catala P, Mornet F, Huet V, Jan B, Vincent D, Sautour B, Montanié H (2010) Pelagic food web patterns: do they modulate virus and nanoflagellate effects on picoplankton during the phytoplankton spring bloom? Environ Microbiol 12:2755-2772

43. Parada V, Sintes E, Van Aken HM, Weinbauer MG, Herndl GJ (2007) Viral abundance, decay, and diversity in the meso- and bathypelagic waters of the North Atlantic. Appl Environ Microbiol 73:4429-4438

44. Peduzzi P, Schiemer F (2004) Bacteria and viruses in the water column of tropical freshwater reservoirs. Environ Microbiol 6:707715

45. Pourriot R, Meybeck M (eds) (1995) Limnologie générale. Masson, Paris, $956 \mathrm{pp}$

46. Pradeep Ram A, Sime-Ngando T (2008) Functional responses of prokaryotes and viruses to grazer effects and nutrient additions in freshwater microcosms. ISME J 2:498-509

47. Pradeep Ram AS, Boucher D, Sime-Ngando T, Debroas D, Romagoux JC (2005) Phage bacteriolysis, protistan bacterivory potential, and bacterial production in a freshwater reservoir: coupling with temperature. Microb Ecol 50:64-72

48. Pradeep Ram AS, Bashir A, Danger M, Carrias JF, Lacroix G, Sime-Ngando T (2010) High and differential viral infection rates within bacterial 'morphopopulations' in a shallow sand pit lake (Lac de Créteil, France). FEMS Microbiol Ecol 74:83-92

49. Pradeep Ram AS, Rasconi S, Jobard M, Palesse S, Colombet J, Sime-Ngando T (2011) High lytic infection rates but low abundances of prokaryote viruses in a humic lake (Vassivière, Massif Central, France). Appl Environ Microbiol 77:5610-5618

50. Proctor L, Fuhrman JA (1990) Viral mortality of marine bacteria and cyanobacteria. Nature 343:60-62

51. Rassoulzadegan F (1993) Protozoan patterns in the AzamAmmerman's bacteria-phytoplankton mutualism. In: Guerrero R, Pedros-Alio C (eds) Trends in microbial ecology. Spanish Society for Microbiology, Barcelona, pp 435-439

52. Sanders RW, Porter KG, Bennett SJ, Debiase AE (1989) Seasonal patterns of bacterivory by flagellates, ciliates, rotifers, and cladocerans in a freshwater planktonic community. Limnol Oceanogr 34:673687

53. Sherr EB, Sherr BF (1987) High rates of consumption of bacteria by pelagic ciliates. Nature 325:710-711 
54. Sime-Ngando T, Bourdier G, Amblard C, Pinel-Alloul B (1991) Short-term variations in specific biovolumes of different bacterial forms in aquatic ecosystems. Microb Ecol 21:211-226

55. Simek K, Pernthaler J, Weinbauer MG, Hornak K, Dolan JR, Nedoma J, Masin M, Amann R (2001) Changes in bacterial community composition and dynamics and viral mortality rates associated with enhanced flagellate grazing in a mesoeutrophic reservoir. Appl Environ Microbiol 67:2723-2733

56. Sime-Ngando T, Bettarel Y, Chartogne C, Sean K (2003) The imprint of wild viruses on freshwater microbial ecology. Recent Res Dev Microbiol 7:481-497

57. Steward GF, Smith DC, Azam F (1996) Abundance and production of bacteria and viruses in the Bering and Chukchi Sea. Mar Ecol Prog Ser 131:287-300

58. Suttle CA (2005) Viruses in the sea. Nature 437:356-361

59. Suttle CA, Chen F (1992) Mechanisms and rates of decay of marine viruses in seawater. Appl Environ Microbiol 58:3721-3729

60. Suttle CA, Chan AM, Cottrell MT (1990) Infection of phytoplankton by viruses and reduction of primary productivity. Nature 347:467-469

61. Tanaka T, Rassoulzadegan F (2002) Full-depth profile (0-2000 m) of bacteria, heterotrophic nanoflagellates and ciliates in NW Mediterranean Sea: vertical partitioning of microbial trophic structures. Deep-Sea Res II 49:2093-2107

62. Tanaka T, Rassoulzadegan F (2004) Vertical and seasonal variations of bacterial abundance and production in the mesopelagic layer of the NW Mediterranean Sea: bottom-up and top-down controls. Deep Sea Res I 51:531-544
63. Tanaka T, Rassoulzadegan F, Thingstad TF (2004) Quantifying the structure of the mesopelagic microbial loop from observed depth profiles of bacteria and protozoa. Biogeosci Discuss 1:413-428

64. Weinbauer MG, Peduzzi P (1994) Frequency, size and distribution of bacteriophages in different marine bacterial morphotypes. Mar Ecol Prog Ser 108:11-20

65. Weinbauer MG, Höfle MG (1998) Significance of viral lysis and flagellate grazing as factors controlling bacterioplankton production in a eutrophic lake. Appl Environ Microbiol 64:431-

66. Weinbauer MG, Höfle MG (1998) Size-specific mortality of lake bacterioplankton by natural virus communities. Aquat Microb Ecol 15:103-113

67. Weinbauer MG, Winter C, Höfle MG (2002) Reconsidering transmission electron microscopy based estimates of viral infection of bacterioplankton using conversion factors derived from natural communities. Aquat Microb Ecol 27:103-110

68. Weinbauer MG, Brettar I, Höfle MG (2003) Lysogeny and virusinduced mortality of bacterioplankton in surface, deep, and anoxic marine waters. Limnol Oceanogr 48:169-177

69. Weinbauer MG, Hornak K, Jezbera J, Nedoma J, Dolan JR, Simek K (2007) Synergistic and antagonistic effects of viral lysis and protistan grazing on bacterial biomass, production and diversity. Environ Microbiol 9:777-788

70. Wommack KE, Colwell RR (2000) Virioplankton: viruses in aquatic ecosystem. Microbiol Mol Biol Rev 64:69-114

71. Zhang R, Weinbauer MG, Qian PY (2007) Viruses and flagellates sustain apparent richness and reduce biomass accumulation of bacterioplankton in coastal marine waters. Environ Microbiol 9:3008-3018 